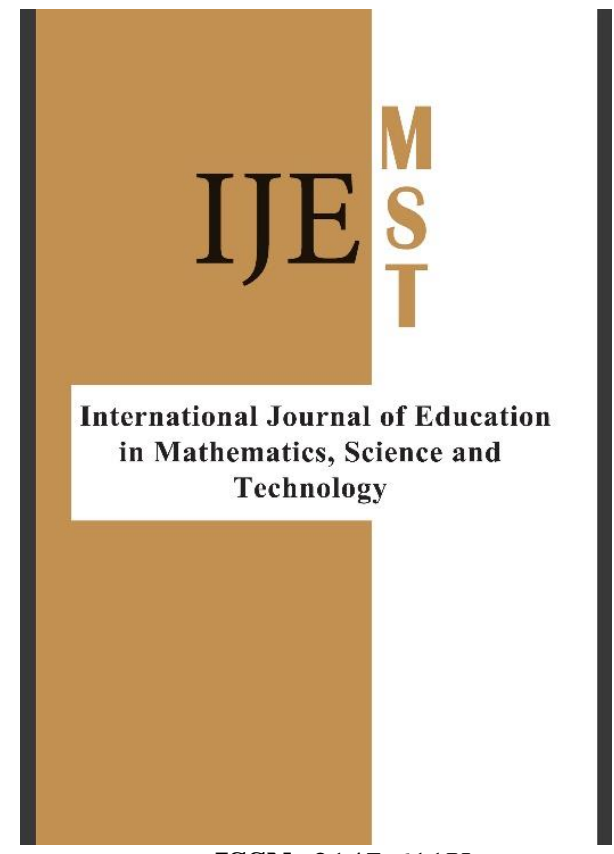

\title{
International Journal of Education in Mathematics, Science and Technology (IJEMST)
}

$\underline{\text { www.ijemst.com }}$

\section{Prediction of Problematic Internet Usage of University Students by Their Attachment Styles}

\section{Ahmet Oguz Akturk}

Necmettin Erbakan University

ISSN: $2147-611 \mathrm{X}$

\section{To cite this article:}

Akturk, A. O. (2020). Prediction of problematic Internet usage of university students by their attachment styles. International Journal of Education in Mathematics, Science and Technology (IJEMST), 8(4), 318-329.

This article may be used for research, teaching, and private study purposes.

Any substantial or systematic reproduction, redistribution, reselling, loan, sub-licensing, systematic supply, or distribution in any form to anyone is expressly forbidden.

Authors alone are responsible for the contents of their articles. The journal owns the copyright of the articles.

The publisher shall not be liable for any loss, actions, claims, proceedings, demand, or costs or damages whatsoever or howsoever caused arising directly or indirectly in connection with or arising out of the use of the research material. 


\section{Prediction of Problematic Internet Usage of University Students by Their Attachment Styles}

\begin{tabular}{|c|c|}
\hline \multicolumn{2}{|r|}{ Ahmet Oguz Akturk } \\
\hline Article Info & Abstract \\
\hline Article History & The purpose of this study is to predict university students problematic \\
\hline Received: & the university students at a large university in Turkey. While the Problematic \\
\hline 01 May 2020 & Internet Usage Scale is used to measure university students' problematic \\
\hline $\begin{array}{l}\text { Accepted: } \\
25 \text { August } 2020\end{array}$ & $\begin{array}{l}\text { Internet usage levels, the Relationship Scales Questionnaire is used to } \\
\text { determine their attachment styles. The Problematic Internet Usage Scale has } \\
\text { the following sub-dimensions: excessive usage, social benefit/social comfort }\end{array}$ \\
\hline Keywords & $\begin{array}{l}\text { and negative consequences of the Internet. The sub-dimensions of the } \\
\text { Relationship Scales Questionnaire involve secure, fearful, preoccupied and }\end{array}$ \\
\hline University students & dismissing. Descriptive statistics, correlation analysis and regression analysis \\
\hline $\begin{array}{l}\text { Problematic Internet } \\
\text { usage }\end{array}$ & $\begin{array}{l}\text { were conducted to analyze the data obtained from the study. Also, correlation } \\
\text { and stepwise regression analysis technique are used to investigate the }\end{array}$ \\
\hline Attachment styles & relationship between the problematic Internet usage and the sub-dimensions of \\
\hline Gender & $\begin{array}{l}\text { the attachment styles. The findings show that the participants have a medium- } \\
\text { level of problematic Internet usage. The male university students are more } \\
\text { inclined to exhibit problematic Internet usage behaviors than the female } \\
\text { students. In addition, the preoccupied, secure and dismissing attachment styles } \\
\text { are found to be the significant predictors of problematic Internet usage. }\end{array}$ \\
\hline
\end{tabular}

\section{Introduction}

The Internet and technology make significant contributions to human life by enabling people to access information within a short time and communicating with other people quickly. In terms of individuals, these contributions may take the forms of making new friends, entertainment, self-presentation, social support, socialization and intercultural interactions (Akturk \& Saka Ozturk, 2019; Alharthi, 2020; Basuhail, 2019; Bixler, 2019; Burch \& Mohammed, 2019; Erdener \& Kandemir, 2019; Gokbel \& Alqurashi, 2018; Kaufman \& Kumar, 2018; Olowo et al., 2020; Omiles et al., 2019; Ozkale \& Koc, 2020; Pambayun et al., 2019; Peker, 2015; Seage \& Türegün, 2020; Serhan, 2019; Syaimar, C.P. \& Sutiarso, 2018; Yerdelen, Osmanoglu \& Tas, 2019). Given that Internet access is increasing rapidly and a little more than half of the world population (51.7 $\%$ ) is Internet users (Internet World Stats, 2017), it is inevitable that the Internet will lead to some problems in addition to affecting human life positively. Individuals experience problems in their academic and social lives due to their uncontrolled and excessive Internet use and these problems may sometimes take on serious dimensions (Davis 2001; Young 1998; Young \& Rodgers, 1998). There are numerous studies indicating that uncontrolled Internet use negatively impacts socio-cultural lives of individuals, reduces time spared for friends and family and increases levels of perceived loneliness (Akturk, 2015; Odac1 \& Kalkan, 2010; Özcan \& Buzlu, 2007; Savc1 \& Aysan, 2017; Shi, Wang, \& Zou, 2017; Shettar, Karkal, Kakunje, Mendonsa, \& Chandran, 2017; Shin, Kim, \& Jang, 2011). It is seen that concepts such as problematic Internet usage (Davis, Flett, \& Besser, 2002), Internet addiction (Young, 1998), excessive use of the Internet (Hansen, 2002), compulsive Internet use (Widyanto \& Griffiths, 2006) addiction to cyberspace (Suler, 2004) are preferred to define the uncontrolled Internet use. However, it would be more appropriate to prefer concepts such as problematic, excessive or maladaptive Internet use owing to the discussions held with regard to the concept of Internet addiction (Beard, 2002; Ceyhan, 2011).

The concept of problematic Internet usage is defined as involving deterioration in important aspects of individuals' lives such as family and business, constant failure experienced in its use and compulsive use (Kim \& Davis, 2009). In this context, problematic Internet usage is described by some researchers (Ceyhan, 2011; Schmitz, 2005; Young, 1998) as a kind of impulsive control disorder. Various researchers are conducting 
studies to determine factors related to problematic Internet use because of the negative effects that problematic Internet usage has on individuals' social and academic lives (Dunbar, Proeve, \& Roberts, 2017; Kabasakal, 2015; Odacı \& Çelik, 2013; Rücker, Akre, Berchtold, \& Suris, 2015; Schimmenti, Passanisi, Gervasi, Manzella, \& Famà, 2014; Yang, Sato, Yamawaki, \& Miyata, 2013). When the relevant literature is investigated, it is seen that attachment styles (Ceritli \& Nedim Bal, 2017; Odacı, \& Çıkrıkçı, 2014; Pednekar, \& Tung, 2017; Shin, Kim, \& Jang, 2011) and gender (Kim \& Davis, 2009; Reiner, Tibubos, Hardt, Müller, Wölfling, \& Beutel, 2017; Willoughby, 2008) are important factors affecting individuals' problematic Internet usage.

Since Internet use has experienced the highest increase among young people in recent years, university students constitute a risk group in terms of problematic Internet usage or Internet addiction (Spada \& Marino, 2017). For, university students may make use of the Internet as part of their education or classes and can access the Internet at their university or dormitory (Akturk \& Sahin, 2010; Akturk, Celik, Sahin, \& Deniz, 2014; Ha, Kim, Bae, Bae, Kim, Sim, Lyoo, \& Cho, 2007; Odac1, 2013). Individuals who experience problems in establishing close relationships in real life may use the Internet uncontrollably due to their need for socialization or belonging to a group (Caplan, 2002; Lin \& Tsai, 2002). Therefore, an investigation of ways of Internet use of individuals who meet their need for making close friends via the Internet may give an idea about what individuals constitute a risk group in terms of problematic Internet usage.

Identification of risk factors that explain university students' problematic Internet usage in order of importance may contribute to efforts aimed at preventing uncontrolled use of the Internet and protecting university students against addiction. In this context, university students' attachment styles according to their age groups and their gender are two critical factors in the prediction of their behaviors. Therefore, determination of what gender and attachment style are risk factors in terms of university students' problematic Internet usage will bring new perspectives to interventions concerning controlled use of the Internet. This study aimed to determine university students' problematic Internet use levels and to find to what extent different attachment styles (secure, fearful, preoccupied and dismissing) predict problematic Internet usage. In addition to these, whether university students' problematic Internet usage varied by the gender factor was investigated.

\section{Attachment Styles}

Attachment is a concept that affects individuals' close relationships of all kinds throughout their lives. Studies on attachment are traditionally based on mother-baby relationships (Quintana \& Lapsley, 1987). According to Bowlby (1980), people are born with an instinctive inclination that motivates them to establish a bond/attachment with other people. According to the Attachment Theory, all through their lives, people use the attachment figures they have developed in their infancy. Initial relationships established with the care giving person constitute individuals' ego/personality and their cognitive schemas, which guides the relationships that will be established (Ditommaso, Brannen-McNulty, Ross, \& Burges, 2003). In other words, attachment can be defined as strong emotional bonds that people develop towards others who they regard important for themselves (Bowlby, 1980; Ainsworth, 1989). In our study, four-category adult attachment styles model developed by Bartholomew and Horowitz (1991) was used as the theoretical basis to suit the sample group. According to this model, there are four attachment styles, namely secure, preoccupied, dismissing and fearful.

Individuals with the secure attachment style possess positive mental representations towards themselves and others. Individuals consider themselves to be lovable and others to be secure (Bartholomew \& Horowitz, 1991). Individuals who are not uncomfortable with establishing close relationships have high levels of self-esteem and autonomy (Buote, Wood, \& Pratt, 2009; Gore \& Rogers, 2010). Individuals with secure attachment cope with stress successfully and maintain a balanced relationship (Koohsar \& Bonab, 2011). Moreover, unfavorable friendships, and bad habits such as cigarette smoking, alcohol and drug addiction are less seen in these individuals who experience a high level of belonging and they are open to learning (Morsümbül \& Çok, 2011; Tambelli, Laghi, Odorisio, \& Notari, 2012).

In the preoccupied attachment style, on the other hand, individuals consider themselves to be worthless while they have a positive opinion of others (Permuy, Merino, \& Fernandez-Rey, 2010). Individuals with the preoccupied style are in a constant state of spending effort to prove themselves as they evaluate themselves from the point of view of others. Although these individuals desire to establish sincere and close friendships, they think that they are not as well regarded as they appreciate their friends and act inconsistently and in a controloriented manner in their relationships (Öztürk \& Mutlu, 2010). They prefer technology-based communication to meet their need for belonging and increase their social communication due to their deep concern about their being rejected or being abandoned (Bartholomew \& Horowitz, 1991). On account of these reasons, individuals 
with the preoccupied attachment style are more likely to use the Internet in an uncontrolled way (Odac1 \& Çıkrıkçı, 2014).

Individuals who develop dismissing attachment have favorable perceptions about themselves but they have negative opinions of others. These individuals consider themselves to be more important and valuable than others. Having extreme self-confidence, these individuals use unreasonable coping strategies in the face if a problem and therefore their close relationships are short-lived and insatiable (Koohsar \& Bonab, 2011). Since they see themselves as above reproach, they may prefer online communication instead of real social communication (Aydoğdu, 2013).

Individuals with the fearful attachment style have unfavorable perceptions about both themselves and others. These individuals who have difficulty establishing close relationships and expressing their feelings possess a low level of self-confidence. Although they are in need of communication due to their loneliness, they have difficulty in establishing close relationships as they find others insincere (Weimer, Kerns, \& Oldenburg, 2004). These individuals, who are at the same time pessimistic about life, wish to solve their problems on their own rather than receiving support from others (Aydoğdu, 2013; Bartholomew \& Horowitz, 1991).

According to some studies in the relevant literature, gender is an important factor in terms of individuals' problematic Internet usage. Some researchers argue that problematic Internet usage exhibits differences with respect to women and men (Balta \& Horzum, 2008; Ceyhan 2008; Ceyhan \& Ceyhan 2007; Kim \& Davis, 2009; Morahan-Martin \& Schumacher, 2000; Sirakaya \& Seferoğlu, 2013). However, problematic Internet usage does not vary by gender in some other studies (Subrahmanyam \& Lin, 2007; Hall \& Parsons, 2001).

\section{Method}

\section{Research Model}

The relational survey model was used in this study. Relational survey models are models that aim to determine the presence and/or degree of variation between two or more variables (Karasar, 2005). The relational survey model enables prediction of the other variable if the situation of a variable in a study is known (Coleman, 1958; Fraenkel \& Wallen, 2001).

\section{Research Group}

The method of convenience sampling was used to determine the research group of the study. Convenience sampling is sampling method that is based on collecting data from volunteering individuals who are close by and easy to reach (Cohen, Manion, \& Morrison, 2013). 283 university students attending the Community College of a large state university in central Turkey, of whom $150(53 \%)$ were male and $133(47 \%)$ were female, participated in this study on a voluntary basis. The ages of the students who participated in the study varied between 18 and $26(\bar{X}=20.33 ; \mathrm{Ss}=1.50)$.

\section{Research Instruments}

"Problematic Internet Usage Scale" and "Relationship Scales Questionnaire" were used to collect the research data.

\section{Problematic Internet Usage Scale}

"Problematic Internet Usage Scale", which was developed by Ceyhan, Ceyhan and Gürcan (2007) was used to determine university students' problematic Internet usage levels. The scale (1) is a 5-item Likert type scale which contains response choices varying from "Not At All Appropriate" to "Totally Appropriate" (5) and consists of 33 items in 3 factors. There are 17 positively stated items in the factor of the scale entitled "negative consequences of the Internet", whereas there are 10 positively stated items in the social benefit/social comfort factor and there are 6 items, 2 positively stated (inversely scored) and 4 negatively stated, in the "excessive usage" factor. The item total score reliability coefficients of the scale vary between 0.25 and 0.70 . In the factor analysis of the scale, the internal consistency coefficient obtained from the responses given by 1658 university 
students, who constituted the working group, to the items of the scale was found to be $(\alpha) 0.95$. The internal consistency coefficients of the three factors forming the scale, on the other hand, were found to be 0.94 for the "negative consequences of the Internet" factor, 0.85 for the "social benefit/social comfort" factor, and 0.75 for the "excessive usage" factor (Ceyhan, Ceyhan, \& Gürcan, 2007). The problematic Internet usage scale is not a scale intended to diagnose individuals with "Internet addiction. High scores that might be obtained from the scale can be regarded as indications demonstrating that individuals' Internet usage has become unhealthy, that the Internet has negatively influenced their lives and that this may lead to a tendency towards addiction (Ceyhan, Ceyhan, \& Gürcan, 2007).

\section{Relationship Scales Questionnaire}

In order to measure university students' attachment styles within the scope of the study, Relationship Scales Questionnaire, which was developed by Griffin and Bartholomew (1994) to measure adult individuals' attachment styles and whose reliability and validity was tested on Turkish university students by Sümer and Güngör (1999), was used. The scale, which was used to determine four different attachment styles, namely "Fearful", "Dismissing", "Secure" and "Preoccupied", is a 7-point Likert scale which has responses choices ranging from "It Does Not Describe Me At All" (1) to "It Totally Describes Me"(7). The attachment styles that will be determined via the scale are measured with a total of 30 items, 6 items for secure and dismissing attachment, 8 items for fearful attachment and 10 items for preoccupied attachment. Internal consistency coefficients of the sub-scales vary between 0.27 and 0.61 (Sümer \& Güngör, 1999). Griffin and Bartholomew (1994) attributed the fact that the low internal consistency coefficients of the Relationship Scales Questionnaire to the fact that different models were involved in the same style and that subscales were measured using few items. In spite of the low internal consistency coefficients obtained for the subscales, the two tests were found to possess an acceptable test retest reliability between the same attachment styles varying between 0.54 and 0.78 (Sümer \& Güngör, 1999). Relevant scale has been used as data collection tool in many researches (Bademci, Karaday1, Pur Karabulut, Kurt, \& Warfa, 2017; Çikrikçi \& Gençdoğan, 2017; Turan, Kocalevent, Quintana, Erdur-Baker, \& Diestelmann, 2016; Odacı \& Çıkrıçı, 2014).

\section{Data Analysis and Interpretation}

Whether or not the data exhibited normal distribution was tested before the analysis. To this end, skewness and kurtosis values were examined on the distributions of the total scores obtained from the scales and the values obtained as a result of calculations were given in Table 1.

Table 1. Skewness and Kurtosis Coefficients of the Subscales

\begin{tabular}{llrr}
\hline Scale & Subscales & \multicolumn{1}{c}{ Skewness } & \multicolumn{1}{c}{ Kurtosis } \\
\hline \multirow{4}{*}{ Problematic } & Negative consequences of the Internet & $1.330(\mathrm{SE}=.168)$ & $1.091(\mathrm{SE}=.334)$ \\
Internet Usage & Social benefit / Social comfort & $.913(\mathrm{SE}=.168)$ & $.224(\mathrm{SE}=.334)$ \\
& Excessive usage & $.085(\mathrm{SE}=.168)$ & $-.304(\mathrm{SE}=.334)$ \\
& Total & $.906(\mathrm{SE}=.168)$ & $.124(\mathrm{SE}=.334)$ \\
\hline \multirow{2}{*}{ Relationship } & Fearful attachment & $.008(\mathrm{SE}=.168)$ & $-.441(\mathrm{SE}=.334)$ \\
Scales & Dismissing attachment & $-.168(\mathrm{SE}=.168)$ & $-.096(\mathrm{SE}=.334)$ \\
Questionnaire & Secure attachment & $.045(\mathrm{SE}=.168)$ & $-.695(\mathrm{SE}=.334)$ \\
& Preoccupied attachment & $.073(\mathrm{SE}=.168)$ & $-.682(\mathrm{SE}=.334)$ \\
\hline
\end{tabular}

When the values given in Table 1 are examined, it is seen that the skewness and kurtosis coefficients calculated for each factor of the Problematic Internet Usage Scale and Relationship Scales Questionnaire are between -1.5 and +1.5 , which indicates that the scores obtained from the factors exhibit normal distribution (Tabachnick \& Fidell, 2007). As a result of this, parametric tests were decided to be used on the data obtained from the scales. Within this scope, descriptive statistics and correlation analysis were used in the analysis of the data obtained from the scales while independent samples t-test was used to determine the differences between the pairs. In addition to this, predictive powers of the attachment styles (fearful, dismissing, secure and preoccupied) concerning the problematic Internet usage was analyzed using the stepwise regression analysis. Before the analysis was conducted, whether or not the analysis met the assumptions of normality, multicollinearity and autocorrelation, which are hypotheses of regression analysis was tested (Akbulut, 2010; Büyüköztürk, 2010; Pallant, 2005). In order to meet the assumption of multicollinearity the value of VIF should not be higher than four, and tolerance should not be smaller than 0.20 (Tabachnick \& Fidell, 2007). The VIF values obtained from the study are between 1.15 and 1.53 whereas tolerance values are between 0.65 and 0.87 . To test the 
autocorrelation, on the other hand, Durbin-Watson coefficient is used. Durbin-Watson value is supposed to be between 1.5 and 2.5. Durbin-Watson value is between 1.74 and 2.01 in the regression models tested in the study. The relevant values indicate that regression assumptions were met. The items of the problematic Internet usage were of the five point likert type and the university students were asked to score the items in the scale items between 1 and 5. The range width of the scale is calculated using the formula (Interval = range width / number of groups) is given in Table 2 .

Table 2. Scale Intervals

\begin{tabular}{cll}
\hline Weight & Option & Intervals \\
\hline 1 & Totally inappropriate & $1.00-1.79$ \\
2 & Rarely appropriate & $1.80-2.59$ \\
3 & A little appropriate & $2.60-3.39$ \\
4 & Fairly appropriate & $3.40-4.19$ \\
5 & Totally appropriate & $4.20-5.00$ \\
\hline
\end{tabular}

\section{Results}

\section{University Students' Problematic Internet Usage Levels}

In order to determine university students' problematic Internet usage levels, the scores which the students received from the "negative consequences of Internet usage", social benefit/social comfort" and excessive usage" sub-dimensions of the problematic Internet usage scale and from the whole of the scale were investigated. Results of the analysis are given in Table 3.

Table 3. University Students' Problematic Internet Usage Levels

\begin{tabular}{llrrrrr}
\hline \multirow{2}{*}{ Scale } & Subscales & \multirow{N}{*}{} & $\begin{array}{r}\text { Minimum } \\
\text { score }\end{array}$ & $\begin{array}{r}\text { Maximum } \\
\text { score }\end{array}$ & $\bar{X}$ & SD \\
\hline Problematic & Negative consequences of the Internet & 283 & 17 & 77 & 28.38 & 12.682 \\
\cline { 2 - 7 } Internet & Social benefit / Social comfort & 283 & 10 & 40 & 18.53 & 7.053 \\
\cline { 2 - 7 } Usage & Excessive usage & 283 & 6 & 30 & 16.71 & 4.983 \\
\hline Total Problematic Internet Usage & 283 & 33 & 147 & 63.62 & 21.902 \\
\hline
\end{tabular}

The findings obtained as a result of the analysis conducted reveal that the score which the university students received from the "negative consequences of the Internet" sub-dimension of the problematic Internet usage scale were $(\bar{X}=28.38)$ within the range of "totally inappropriate", the scores they received from the "social benefit/social comfort" sub-dimension were $(\bar{X}=18.53)$ within the range of "rarely appropriate", the scores they received from the "excessive usage" were $(\bar{X}=16.71)$ within the range of "a little appropriate" and the scores they received from the whole of the problematic Internet usage scale were $(\bar{X}=63.62)$ within the range of "rarely appropriate". According to this, it can be said that in general university students exhibit a low level of problematic Internet usage.

\section{The Problematic Internet Usage of University Students According to Gender}

Whether or not university students' problematic Internet usage levels varied by gender were analyzes using independent samples t-test and the results of the analysis are given in Table 4.

Table 4. The Problematic Internet Usage of University Students according to Gender

\begin{tabular}{|c|c|c|c|c|c|c|c|}
\hline Scale & Subscales & Gender & $\mathrm{N}$ & $\bar{X}$ & SD & $\mathrm{t}$ & $\mathrm{p}$ \\
\hline \multirow{6}{*}{$\begin{array}{l}\text { Problematic } \\
\text { Internet } \\
\text { Usage }\end{array}$} & \multirow{2}{*}{ Negative consequences of the Internet } & Male & 150 & 32.08 & 14.706 & \multirow{2}{*}{5.024} & \multirow{2}{*}{.000} \\
\hline & & Female & 133 & 24.13 & 8.036 & & \\
\hline & \multirow{2}{*}{ Social benefit / Social comfort } & Male & 150 & 20.53 & 7.704 & \multirow{2}{*}{4.814} & \multirow{2}{*}{.000} \\
\hline & & Female & 133 & 16.23 & 5.402 & & \\
\hline & \multirow{2}{*}{ Excessive usage } & Male & 150 & 17.77 & 4.582 & \multirow{2}{*}{3.417} & \multirow{2}{*}{.001} \\
\hline & & Female & 133 & 15.50 & 5.170 & & \\
\hline \multirow{2}{*}{\multicolumn{2}{|c|}{ Total Problematic Internet Usage }} & Male & 150 & 70.38 & 24.174 & \multirow{2}{*}{5.295} & \multirow{2}{*}{.000} \\
\hline & & Female & 133 & 55.86 & 15.822 & & \\
\hline
\end{tabular}


When the values given in Table 4 are examined, it is seen that there is a significant difference with regard to gender in the score which university students received from the "Negative Consequences of the Internet $(\mathrm{t}=5.024 ; p<0.01)$ ", "Social benefit/Social comfort $(\mathrm{t}=4.814 ; p<0.01)$ " and "Excessive Usage $(\mathrm{t}=3.417 ; p<0.01)$ " sub-dimensions of the problematic Internet usage scale and in the "total problematic Internet usage $(\mathrm{t}=5.295$; $p<0.01)$ ". According to these results, male university students $(\bar{X}=70.38)$ are in general more inclined to problematic Internet usage than female university students $(\bar{X}=55.86)$.

\section{Relationships between Variables}

Pearson Product Moment Correlation Coefficient was used in the analysis of the relationships between university students' problematic Internet usage levels and their attachment styles (fearful, dismissing, secure and preoccupied). The relationships between problematic Internet usage, which was the dependent variable of the study, and secure and preoccupied attachment styles, which were of predictive variables, were positive and statistically significant (see Table 5).

Table 5. Relationships between Variables

\begin{tabular}{lccccc}
\hline Variable & 1 & 2 & 3 & 4 & 5 \\
\hline 1. Problematic Internet usage & - & & & & \\
2. Fearful attachment & $.207^{* *}$ & - & & & \\
3. Dismissing attachment & .032 & $.541^{* *}$ & \multicolumn{1}{c}{-} & & \\
4. Secure attachment & $.364^{* *}$ & $.264^{* *}$ & $.216^{* *}$ & - & \\
5. Preoccupied attachment & $.433^{* *}$ & $.618^{* *}$ & $.357^{* *}$ & $.538^{* *}$ & - \\
& & & & & \\
Mean & 63.62 & 32.84 & 27.52 & 24.06 & 37.33 \\
Standard deviation & 21.90 & 8.69 & 6.34 & 7.19 & 12.43 \\
\hline
\end{tabular}

**. Correlation is significant at the 0.01 level (2-tailed).

Factors predicting university students' problematic Internet usage levels were investigated through stepwise regression analysis. In this way, the variables which made a significant contribution to the prediction of problematic Internet usage and the contribution of each of these variables to the total variance explained in the prediction of problematic Internet usage were determined. As a result of 3 stages (models) in the application of this method, total variance accounted for in the problematic Internet usage was identified (see Table 6).

Table 6. Results of the Stepwise Regression Analysis Concerning the Predictors of Problematic Internet Usage

\begin{tabular}{cccccccccc}
\hline Model $^{\mathrm{a}}$ & $\mathrm{R}$ & $\mathrm{R}^{2}$ & Adjusted R $^{2}$ & $\mathrm{SE}$ & $\mathrm{R}^{2}$ change & $\mathrm{F}$ change & $\mathrm{sd}_{1}$ & $\mathrm{sd}_{2}$ & $\mathrm{p}$ \\
\hline $1^{\mathrm{b}}$ & .433 & .187 & .183 & 19.793 & .187 & 49.476 & 1 & 281 & .000 \\
$2^{\mathrm{c}}$ & .460 & .211 & .204 & 19.540 & .024 & 6.614 & 1 & 280 & .011 \\
$3^{\mathrm{d}}$ & .480 & .230 & .219 & 19.355 & .019 & 5.119 & 1 & 279 & .025 \\
\hline
\end{tabular}

${ }^{a}$ Dependent variable: Problematic Internet usage

${ }^{\mathrm{b}}$ Predictors: (constant), Preoccupied attachment

${ }^{\mathrm{c}}$ Predictors: (constant), Preoccupied attachment, Secure attachment

${ }^{\mathrm{d}}$ Predictors: (constant), Preoccupied attachment, Secure attachment, Dismissing attachment

In the first model (see Table 6), preoccupied attachment regression equality, one of the attachment styles, was entered into the analysis. It explained $18.7 \%$ of the variance in problematic Internet usage. In other words, the strongest predictor of the problematic Internet usage was found to be preoccupied attachment style.

In the second model, secure attachment, one of the attachment styles, was added to the model and with the addition of secure attachment. Then, the variance explained in the problematic Internet usage score rose from $18.7 \%$ to $21.1 \%$. In other words, secure attachment is seen to have made a contribution of $2.4 \%$ to the explained variance.

In the third model, dismissing attachment, one of the attachment styles, was added to the model and with the addition of this attachment style. Then, the variance explained in the problematic Internet usage rose from 21.1 $\%$ to $23.0 \%$. Here, the $1.9 \%$ contribution made by dismissing attachment to the explained variance can be regarded as low compared with the contributions of the other attachment styles. 


\section{Discussion and Conclusion}

This study was conducted to determine university students' problematic Internet usage levels and reveal the relationships between attachment styles and problematic Internet usage. In addition, whether university students' problematic Internet use levels varied by the gender factor was identified. When the findings arrived at as a result of the study are examined, firstly, it is observed that university students' problematic Internet usage is generally at a low level. On the other hand, the problematic Internet usage of preservice teachers was found to be at an intermediate level in a study conducted by Sirakaya and Seferoğlu (2013). In another study conducted by Ata, Akpınar and Kelleci (2011), the problematic Internet use levels of the participants were found to be low similar to the finding of our study.

According to another finding of this study, problematic Internet use levels of male university students are higher than those of female ones. Male students had higher mean scores in all subdimensions of the problematic Internet usage in addition to general problematic Internet usage. In other words, male students use the Internet more than female ones for purposes of social benefit and social comfort and are more influenced by negative consequences of the Internet. When studies conducted in this respect are examined, it is seen that there are several studies indicating that problematic Internet use levels of men are higher than those of women (Batıgün \& Kılıç, 2011; Çelik \& Odac1, 2012; Gürcan, 2010; Mottram \& Fleming, 2009; Yang \& Tung, 2007). Similar to the findings of this study, it was found in Sirakaya and Seferoğlu's (2013) study that male university students had higher scores than female ones in the whole and subdimensions of the problematic Internet usage. In addition to this, given that one of the most important of the university students' reasons for using the Internet concerns social media, it has been stated in some studies that male students use social media more than female ones (Dhir, Khalil, Lonka, \& Tsai, 2017). The fact that men use social networks more than girls can be proposed as a reason for their problematic Internet usage.

According to another finding obtained in the study, there is a positive correlation between university students' problematic Internet usage and their fearful, preoccupied and secure attachment styles. Preoccupied individuals have difficulty in establishing relationships in their social lives due to the fact that they feel themselves worthless and have a need for belonging. This situation may lead them to online communication in the name of providing satisfaction which they fail to obtain in real life relationships (Howard \& Medway, 2004; Çelik \& Odac1, 2012). Likewise, it has been stated that individuals with the fearful attachment style who have high levels of social anxiety and have difficulty establishing close relationships are more inclined to prefer communication based on technology (Öztürk \& Mutlu, 2010). It was argued in Ceritli and Nedim Bal's (2017) study that preoccupied individuals and fearful individuals who are closed to the outside in real life and have high levels of social anxiety prefer the Internet more to establish communication due to its social convenience. Similar to the finding of the present study, Shin, Kim and Jang (2011) found in the study they conducted that individual having high levels of anxiety and avoidance and fearful attachment style suffered from problematic Internet usage than others. Unlike the studies conducted in the relevant literature (Ceritli \& Nedim Bal, 2017; Odac1 \& Çıkrıkç1, 2014; Savcı \& Aysan, 2016), there was a positive relationship between the secure attachment style of individuals and their problematic Internet usage. Individuals with the secure attachment style regard themselves as lovable/popular and others as reliable/secure (Bartholomew \& Horowitz, 1991). At the same time, these individuals do not feel disturbed when they establish close relationships. Given that individuals use the Internet to communicate with close friends with whom they meet in real life and that the Internet is a means that strengthens peer relationships (Gross, 2004; Subrahmanyam \& Lin, 2007), even individuals with the secure attachment style may at times not control their Internet use. Within this framework, even attachment styles of these individuals were secure in close relationships; their ways of Internet use may be uncontrolled. In related literature, some studies indicate that electronic communication is particularly useful for long-term relationships (Boneva, Kraut, \&Frohlich, 2001; Dainton \& Aylor, 2002; Morey, Gentzler, Creasy, Oberhauser, \& Westerman, 2013; Stephen, 1986). Several technologies can be utilized in this process, from e-mail to social networks (Tong \& Walther, 2011). Electronic communication is also found to enhance mutual self-disclosure and emotional intimacy (Cooper \& Sportolari, 1997). Therefore, individuals with the secure attachment style make use of the Internet to reinforce their close relationships but fail to check/control their Internet use.

According to a finding reached as a result of the stepwise regression analysis, preoccupied and secure attachment styles, together with the dismissing attachment style, account for $23 \%$ of the variance in problematic Internet use. According to the regression model that was formed, the most important factor affecting university students' problematic Internet usage is the preoccupied attachment style. Although there is no correlational dual relationship between the dismissing attachment style and problematic Internet usage, the dismissing attachment style affects problematic Internet usage. The significance level of the secure attachment style increased when the dismissing attachment style was included in the regression model. In this context, it can be argued that the 
dismissing attachment style has an indirect effect on problematic Internet usage via the secure attachment style. Similar to this study, Odacı and Çıkrıkçı (2014) found in their study a statistically significant correlation between the dismissing attachment style and problematic Internet usage. Since individuals with the dismissing attachment style do not like to reveal their feelings and ideas (Bartholomew \& Horowitz, 1991), they may want to find the kind of relationships they desire in online environment. This may bring their problematic Internet usage to an uncontrolled state. Since individuals with the dismissing attachment style regard other people less important and worthy than themselves, they may isolate themselves from social life and join online media where they may more freely reveal their personality features (Monacis, de Palo, Griffiths, \& Sinatra, 2017).

\section{Recommendations}

The purpose of this study is to determine university students' problematic Internet use levels and reveal the relationships between attachment styles and problematic Internet usage. According to the results obtained in the study, there is a positive relationship between university students' problematic Internet usage and fearful, preoccupied and secure attachment styles. Contrary to the relevant literature, it was concluded in this study that problematic Internet usage of even individuals with the secure attachment style might be uncontrolled. Therefore, individuals with the attachment style must not be ignored in seminars and training sessions intended for university students' problematic Internet usage. This finding by this study may be regarded as a contribution to the relevant literature. In this context, there is a need for more studies concerning the relevant result. The result of this study is that, similar to the previous studies, gender is an important variable with regard to problematic Internet usage. Male university students use the Internet more than female counterparts to meet their need for social benefit/social comfort and are more affected by the negative effects of the Internet.

\section{References}

Ainsworth, M. D. S. (1989). Attachments beyond infancy. American Psychologist, 44(4), 709-716.

Akbulut, Y. (2010). Sosyal bilimlerde SPSS uygulamalarl [SPSS applications in social sciences]. İstanbul: İdeal Kültür Publishing.

Akturk, A. O. (2015). Analysis of cyberbullying sensitivity levels of high school students and their perceived social support levels. Interactive Technology and Smart Education, 12(1), 44-61.

Akturk, A. O., Celik, I., Sahin, I., \& Deniz, M. E. (2014). Turkish adaptation study of Facebook connection strategies scale, Elementary Education Online, 13(1), 319-333.

Akturk, A. O., \& Sahin, I. (2010). Analysis of community college students' educational Internet use and metacognitive learning strategies. Procedia-Social and Behavioral Sciences, 2(2), 5581-5585.

Akturk, A.O. \& Saka Ozturk, H. (2019). Teachers' TPACK levels and students' self-efficacy as predictors of students' academic achievement. International Journal of Research in Education and Science (IJRES), 5(1), 283-294.

Alharthi, M. (2020). Students' attitudes toward the use of technology in online courses. International Journal of Technology in Education (IJTE), 3(1), 14-23.

Ata, Akpınar, \& Kelleci, (2011). The relationship between students problematic Internet usage and their anger expression manner. TAF Preventive Medicine Bulletin, 10(4), 473-480.

Aydoğdu, T. (2013). Bağlanma stilleri, başa çıkma stratejileri ile psikolojik dayanıklılık arasındaki ilişkinin incelenmesi [Attachment styles, coping strategies between psychological hardiness examining of the relationships]. (Unpublished Master Thesis), Gazi University, Institute of Educational Sciences, Ankara.

Bademci, H. Ö., Karadayı, E. F., Pur Karabulut, İ. G., Kurt, Z., \& Warfa, N. (2017). Improving psychosocial well-being of child laborers and young people who are engaged in low-income economic activities in Istanbul, Turkey. Child \& Youth Services, 1-13.

Balta, Ö. Ç., \& Horzum, M. B. (2008). Web tabanlı öğretim ortamındaki Internet bağımlılığını etkileyen faktörler [The factors that affect Internet addiction of students in a web based learning environment]. Ankara Üniversitesi Eğitim Bilimleri Fakültesi Dergisi [Ankara University, Journal of Faculty of Educational Sciences], 41(1), 187-205.

Bartholomew, K., \& Horowitz, L. M. (1991). Attachment styles among young adults: A test of a four-category model. Journal of personality and social psychology, 61(2), 226-244.

Basuhail, A. (2019). e-Learning objects designing approach for programming-based problem solving. International Journal of Technology in Education (IJTE), 2(1), 32-41.

Batıgün, A. D., \& Kılıç, N. (2011). The relationships between internet addiction, social support, psychological symptoms and some socio-demographical variables. Turkish Journal of Psychology, 26(67), 1-13. 
Beard, K. W. (2002). Internet addiction: Current status and implications for employees. Journal of Employment Counseling, 39(1), 2-11.

Bixler, S. (2019). One-to-one iPad technology in the middle school mathematics and science classrooms. International Journal of Technology in Education and Science (IJTES), 3(1), 1-18.

Boneva, B., Kraut, R., \& Frohlich, D. (2001). Using e-mail for personal relationships: The difference gender makes. American Behavioral Scientist, 45(3), 530-549.

Bowlby, J. (1980). Attachment and loss: Vol. 3. Loss: Sadness and depression. New York: Basic Books.

Buote, V. M., Wood, E., \& Pratt, M. (2009). Exploring similarities and differences between online and offline friendships: The role of attachment style. Computers in Human Behavior, 25(2), 560-567.

Burch, Z.A. \& Mohammed, S. (2019). Exploring faculty perceptions about classroom technology integration and acceptance: A literature review. International Journal of Research in Education and Science (IJRES), 5(2), 722-729.

Büyüköztürk, Ş. (2010). Sosyal bilimler için veri analiz el kitabı [Data analysis handbook for social sciences]. Ankara: Pegem Academy Publishing.

Caplan, S. E. (2002). Problematic Internet use and psychosocial well-being: development of a theory based cognitive behavioral measurement instrument. Computers in Human Behavior, 18(5), 553-575.

Çelik, Ç. B., \& Odac1, H. (2012). The predictive role of self-esteem and self-perception on problematic Internet use. Education Sciences, 7(1), 433-441.

Ceritli, U., \& Nedim Bal, P. (2017). The effect of attachment styles on problematic Internet use in high school students. The Journal of International Social Research, 10(50), 475-483.

Ceyhan, A. (2008). Predictors of problematic Internet use on Turkish university students. CyberPsychology \& Behavior, 11(3), 363-366.

Ceyhan, A. A. (2011). University students' problematic Internet use and communication skills according to the Internet use purposes. Educational Sciences: Theory \& Practice, 11(1), 69-77.

Ceyhan, E. ve Ceyhan, A. A. (2007). An investigation of problematic Internet usage behaviors on Turkish university students. Proceedings of 7th International Educational Technology Conference (pp. 115-120). Near East University, North Cyprus.

Ceyhan, E., Ceyhan, A. A., \& Gürcan, A. (2007). Problemli Internet Kullanımı Ölçeği’nin geçerlik ve güvenirlik çalışmaları [The validity and reliability of the Problematic Internet Usage Scale]. Kuram ve Uygulamada Eğitim Bilimleri [Educational Sciences: Theory \& Practice], 7(1), 387-416.

Çikrikçi, Ö., \& Gençdoğan, B. (2017). The effects of attachment styles and belongingness on life satisfaction among adolescents. International Journal of Happiness and Development, 3(3), 241-255.

Cohen, L., Manion, L., \& Morrison, K. (2013). Research methods in education. London: Routledge.

Coleman, J. (1958). Relational analysis: The study of social organizations with survey methods. Human Organization, 17(4), 28-36.

Cooper, A., \& Sportolari, L. (1997). Romance in cyberspace: Understanding online attraction. Journal of Sex Education and Therapy, 22(1), 7-14.

Dainton, M., \& Aylor, B. (2002). Patterns of communication channel use in the maintenance of long-distance relationships. Communication Research Reports, 19(2), 118-129.

Davis, R. A. (2001). A cognitive-behavioral model of pathological Internet use. Computers in Human Behavior, 17(2), 187-195.

Davis, R. A., Flett, G. L., \& Besser, A. (2002). Validation of a new scale for measuring problematic Internet use: Implications for pre-employment screening. CyberPsychology \& Behavior, 5(4), 331-345.

Dhir, A., Khalil, A., Lonka, K., \& Tsai, C. C. (2017). Do educational affordances and gratifications drive intensive Facebook use among adolescents? Computers in Human Behavior, 68, 40-50.

Ditommaso, E., Brannen-McNulty, C., Ross, L., \& Burges, M. (2003). Attachment styles, social skills and loneliness in young adults. Personality and Individual Differences, 35(2), 303-312.

Dunbar, D., Proeve, M., \& Roberts, R. (2017). Problematic Internet usage self-regulation dilemmas: Effects of presentation format on perceived value of behavior. Computers in Human Behavior, 70, 453-459.

Erdener, K. \& Kandemir, M.A. (2019). Investigation of the reasons for students' attitudes towards the interactive whiteboard use in mathematics classrooms. International Journal of Research in Education and Science (IJRES), 5(1), 331-345.

Fraenkel, J. R., \& Wallen, N. E. (2006). How to design and evaluate research in education (6 th ed.). New York, NY: McGraw-Hill.

Gore, J. S., \& Rogers, M. J. (2010). Why do I study? The moderating effect of attachment style on academic motivation. The Journal of Social Psychology, 150(5), 560-578.

Griffin, D., \& Bartholomew, K. (1994). Models of the self and other: Fundamental dimensions underlying measures of adult attachment. Journal of Personality and Social Psychology, 67(3), 430-445.

Gokbel, E.N. \& Alqurashi, E. (2018). Technology professional development and mathematics achievement: The change over the years. International Journal of Technology in Education (IJTE), 1(1), 19-28. 
Gross, E. F. (2004). Adolescent Internet use: What we expect, what teens report. Journal of Applied Developmental Psychology, 25(6), 633-649.

Gürcan, N. (2010). Ergenlerin problemli Internet kullanımlarl ile uyumlarl arasındaki ilişkinin incelenmesi [Examination of the relationship between adolescent' problematic Internet use and the adaptation]. (Unpublished Master Thesis), Selçuk University, Institute of Educational Sciences, Konya.

Ha, J. H., Kim, S. Y., Bae, S. C., Bae, S., Kim, H., Sim, M., Lyoo, I. K., \& Cho, S. C. (2007). Depression and Internet addiction in adolescents. Psychopathology, 40(6), 424-430.

Hall, A. S., \& Parsons, J. (2001). Internet addiction: College student case study using best practices in cognitive behavior therapy. Journal of Mental Health Counseling, 23(4), 312-327.

Hansen, S. (2002). Excessive Internet usage or Internet addiction? The implications of diagnostic criteria for student users. Journal of Computer Assisted Learning, 18(2), 235-236.

Howard, M. S., \& Medway, F. J. (2004). Adolescents' attachment and coping with stress. Psychology in the Schools, 41(3), 391-402.

Internet World Stats. (2017). Internet usage statistics: The Internet big picture world Internet users and 2017 population stats. Retrieved November 17, 2017, from http://www.Internetworldstats.com/stats.htm

Kabasakal, Z. (2015). Life satisfaction and family functions as-predictors of problematic Internet use in university students. Computers in Human Behavior, 53, 294-304.

Karasar, N. (2005). Bilimsel araştırma yöntemi [Scientific research method]. Ankara: Nobel Publishing.

Kaufman, D. \& Kumar, S. (2018). Student perceptions of a one-to-one iPad program in an urban high school. International Journal of Research in Education and Science (IJRES), 4(2), 454-470.

Kim, H. K., \& Davis, K. E. (2009). Toward a comprehensive theory of problematic Internet use: Evaluating the role of self-esteem, anxiety, flow, and the self-rated importance of Internet activities. Computers in Human Behavior, 25(2), 490-500.

Koohsar, A. A. H., \& Bonab, B. G. (2011). Relation between quality of attachment and life satisfaction in high school administrators. Procedia-Social and Behavioral Sciences, 30, 954-958.

Lin, S. S. J., \& Tsai, C. C. (2002). Sensation seeking and Internet dependence of Taiwanese high school adolescent. Computers in Human Behavior, 18(4), 411-426.

Monacis, L., de Palo, V., Griffiths, M. D., \& Sinatra, M. (2017). Exploring individual differences in online addictions: The role of identity and attachment. International Journal of Mental Health and Addiction, 15(4), 853-868.

Morahan-Martin, J., \& Schumacher, P. (2000). Incidence and correlates of pathological Internet use among college students. Computers in Human Behavior, 16(1), 13-29.

Morey, J. N., Gentzler, A. L., Creasy, B., Oberhauser, A. M., \& Westerman, D. (2013). Young adults' use of communication technology within their romantic relationships and associations with attachment style. Computers in Human Behavior, 29(4), 1771-1778.

Morsünbül, Ü., \& Çok, F. (2011). Bağlanma ve ilişkili değişkenler [Attachment and Related Variables]. Psikiyatride Güncel Yaklaşımlar [Current Approaches in Psychiatry], 3(3), 553-570.

Mottram, J. A., \& Fleming, J. F. (2009). Extraversion, impulsivity, and online group membership as predictors of problematic Internet use. CyberPsychology \& Behavior, 12(3), 319-321.

Odac1, H. (2013). Risk-taking behavior and academic self-efficacy as variables accounting for problematic Internet use in adolescent university students. Children and Youth Services Review, 35(1), 183-187.

Odac1, H., \& Çelik, Ç. B. (2013). Who are problematic Internet users? An investigation of the correlations between problematic Internet use and shyness, loneliness, narcissism, aggression and selfperception. Computers in Human Behavior, 29(6), 2382-2387.

Odacı, H., \& Çıkrıkçı, Ö. (2014). Problematic Internet use in terms of gender, attachment styles and subjective well-being in university students. Computers in Human Behavior, 32, 61-66.

Odac1, H., \& Kalkan, M. (2010). Problematic Internet use, loneliness and dating anxiety among young adult university students. Computers \& Education, 55(3), 1091-1097.

Olowo, B. F., Alabi, F. O., Okotoni, C. A., \& Yusuf, M. A. (2020). Social Media: Online Modern Tool to Enhance Secondary Schools Students' Academic Performance. International Journal on Studies in Education, 2(1), 26-35.

Omiles, M. E., Dumlao, J. B., Rubio, Q. K. C., \& Ramirez, E. J. D. (2019). Development of the 21st Century Skills through Educational Video Clips. International Journal on Studies in Education, 1(1), 11-20.

Ozkale, A. \& Koc, M. (2020). Investigating academicians' use of tablet PC from the perspectives of human computer interaction and Technology Acceptance Model. International Journal of Technology in Education and Science (IJTES), 4(1), 37-52.

Özcan, N. K., \& Buzlu, S. (2007). Internet use and its relation with the psychosocial situation for a sample of university students. CyberPsychology \& Behavior, 10(6), 767-772.

Öztürk, A., \& Mutlu, T. (2010). The relationship attachment styles, subjective well-being, happiness and social anxiety among university students. Procedia-Social and Behavioral Sciences, 9, 1772-1776. 
Pallant, J. (2005). SPSS survival manual. A step by step guide to data analysis using SPSS for Windows. Australia: Australian Copyright.

Pambayun, B., Wirjawan, J. V., Wijaya, A., Untung, G. B., \& Pratidhina, E. (2019). Designing mobile learning app to help high school students to learn simple harmonic motion. International Journal on Social and Education Sciences, 1(1), 24-29.

Pednekar, N. K., \& Tung, S. (2017). Problematic Internet use in adolescents: Role of identity styles, emotional autonomy, attachment, family environment and well-being. Indian Journal of Health \& Wellbeing, 8(4), 258-262.

Peker, A. (2015). Analyzing the risk factors predicting the cyberbullying status of secondary school students. Education and Science, 40(181), 57-75.

Permuy, B., Merino, H., \& Fernandez-Rey, J. (2010). Adult attachment styles and cognitive vulnerability to depression in a sample of undergraduate students: The mediational roles of sociotropy and autonomy. International Journal of Psychology, 45(1), 21-27.

Quintana, S. M., \& Lapsley, D. K. (1987). Adolescent attachment and ego identity: A structural equations approach to the continuity of adaptation. Journal of Adolescent Research, 2(4), 393-409.

Reiner, I., Tibubos, A. N., Hardt, J., Müller, K., Wölfling, K., \& Beutel, M. E. (2017). Peer attachment, specific patterns of Internet use and problematic Internet use in male and female adolescents. European Child \& Adolescent Psychiatry, 26(10), 1257-1268.

Rücker, J., Akre, C., Berchtold, A., \& Suris, J. C. (2015). Problematic Internet use is associated with substance use in young adolescents. Acta Paediatrica, 104(5), 504-507.

Savc1, M. \& Aysan, F. (2016). The role of attachment styles, peer relations, and affections in predicting Internet addiction. Addicta: The Turkish Journal on Addictions, 3(3), 416-432.

Savc1, M., \& Aysan, F. (2017). Social-emotional model of Internet addiction. Psychiatry and Clinical Psychopharmacology, 27(4), 349-358.

Schimmenti, A., Passanisi, A., Gervasi, A. M., Manzella, S., \& Famà, F. I. (2014). Insecure attachment attitudes in the onset of problematic Internet use among late adolescents. Child Psychiatry \& Human Development, 45(5), 588-595.

Schmitz, J. M. (2005). The interface between impulse-control disorders and addictions: Are pleasure pathway responses shared neurobiological substrates? Sexual Addiction \& Compulsivity, 12, 149-168.

Seage, S.J., \& Türegün, M. (2020). The effects of blended learning on STEM achievement of elementary school students. International Journal of Research in Education and Science (IJRES), 6(1), 133-140.

Serhan, D. (2019). Web-Based Homework Systems: Students' Perceptions of Course Interaction and Learning in Mathematics. International Journal on Social and Education Sciences, 1(2), 57-62.

Shettar, M., Karkal, R., Kakunje, A., Mendonsa, R. D., \& Chandran, V. M. (2017). Facebook addiction and loneliness in the post-graduate students of a university in southern India. International Journal of Social Psychiatry, 63(4), 325-329.

Shi, X., Wang, J., \& Zou, H. (2017). Family functioning and Internet addiction among Chinese adolescents: The mediating roles of self-esteem and loneliness. Computers in Human Behavior, 76, 201-210.

Shin, S. E., Kim, N. S., \& Jang, E. Y. (2011). Comparison of problematic Internet and alcohol use and attachment styles among industrial workers in Korea. Cyberpsychology, Behavior, and Social Networking, 14(11), 665-672.

Surakaya, M., \& Seferoğlu, S. S. (2013). Investigation of problematic Internet usage of teacher candidates. Hacettepe University Journal of Education, 28(1), 356-368.

Spada, M. M., \& Marino, C. (2017). Metacognitions and emotion regulation as predictors of problematic Internet use in adolescents. Clinical Neuropsychiatry, 14(1), 59-63.

Stephen, T. (1986). Communication and interdependence in geographically separated relationships. Human Communication Research, 13(2), 191-210.

Subrahmanyam, K., \& Lin, G. (2007). Adolescent on the net: Internet use and well-being. Adolescence, 42(168), 659-677.

Suler, J. (2004). The online disinhibition effect. CyberPsychology \& Behavior, 7(3), 321-326.

Sümer, N., \& Güngör, D. (1999). Yetişkin bağlanma stilleri ölçeklerinin Türk örneklemi üzerinde psikometrik değerlendirmesi ve kültürlerarası bir karşılaştırma [Psychometric evaluation of adult attachment measures on Turkish samples and a cross-cultural comparison]. Türk Psikoloji Dergisi [Turkish Journal of Psychology], 14(43), 71-109.

Syaimar, C.P. \& Sutiarso, S. (2018). Study anywhere and anytime, not necessarily in class. International Journal of Technology in Education and Science (IJTES), 2(1), 35-39.

Tabachnick, B. G., \& Fidell, L. S. (2007). Using Multivariate Statistics. Boston, MA: Pearson Education.

Tambelli, R., Laghi, F., Odorisio, F., \& Notari, V. (2012). Attachment relationships and internalizing and externalizing problems among Italian adolescents. Children and Youth Services Review, 34(8), 14651471. 
Tong, S. T., \& Walther, J. B. (2011). Relational maintenance and CMC. In K. B. Wright \& L. M. Webb (Eds.), Computer-mediated Communication and Personal Relationships (pp. 98-118). New York: Peter Lang Publishing.

Turan, N., Kocalevent, R. D., Quintana, S. M., Erdur-Baker, Ö., \& Diestelmann, J. (2016). Attachment orientations: Predicting psychological distress in German and Turkish samples. Journal of Counseling \& Development, 94(1), 91-102.

Weimer, B. L., Kerns, K. A., \& Oldenburg, C. M. (2004). Adolescents' interactions with a best friend: Associations with attachment style. Journal of Experimental Child Psychology, 88(1), 102-120.

Widyanto, L., \& Griffiths, M. D. (2006). Internet addiction: A critical review. International Journal of Mental Health and Addiction, 4, 31-51.

Willoughby, T. A. (2008). Short-term longitudinal study of Internet and computer game use by adolescent boys and girls: Prevalence, frequency of use, and psychosocial predictors. Developmental Psychology, 44(1), 195-204.

Yang, C. Y., Sato, T., Yamawaki, N., \& Miyata, M. (2013). Prevalence and risk factors of problematic Internet use: A cross-national comparison of Japanese and Chinese university students. Transcultural Psychiatry, 50(2), 263-279.

Yang, S. C., \& Tung, C. J. (2007). Comparison of Internet addicts and non-addicts in Taiwanese high school. Computers in Human Behavior, 23(1), 79-96.

Yerdelen, S., Osmanoglu, A., \& Tas, Y. (2019). The influence of a teaching practice course with video-case enriched microteaching on prospective teachers' self-efficacy for teaching. International Journal of Research in Education and Science (IJRES), 5(2), 560-573.

Young, K. S. (1998). Internet addiction: The emergence of a new clinical disorder. CyberPsychology \& Behavior, 1(3), 237-244.

Young, K. S., \& Rodgers, R. (1998). The relationship between depression and Internet addiction. CyberPsychology \& Behavior, 1(1), 25-28.

\section{Author Information}

\begin{tabular}{l}
\hline Ahmet Oguz Akturk \\
Necmettin Erbakan University \\
Turkey \\
Contact e-mail: aoakturk@erbakan.edu.tr \\
\hline
\end{tabular}

